\title{
Percepcja tekstu w formie drukowanej i elektronicznej
}

\author{
Katarzyna Tałuć, Jacek Tomaszczyk \\ Instytut Bibliotekoznawstwa i Informacji Naukowej, \\ Uniwersytet Śląsi w Katowicach
}

\begin{abstract}
Abstrakt
Cel/Teza: Upowszechnienie technologii informacyjno-komunikacyjnych, czego odzwierciedleniem jest rosnąca dostępność tekstów w cyfrowej formie, jak i urządzeń umożliwiających ich odbiór (laptopów, tabletów, smartfonów), skłania do objęcia badaniami zachowań czytelniczych w kontekście rosnącej popularności e-tekstów i ich nośników. Celem artykułu jest przedstawienie wyników badań percepcji i recepcji tekstu czytanego w wersji drukowanej oraz elektronicznej. Autorzy odpowiadają na pytanie badawcze, czy nośnik tekstu wpływa na percepcję tekstu.

Koncepcja/Metody badań: Przeprowadzono eksperyment wśród studentów, których zadaniem było przeczytanie tekstu i udzielenie odpowiedzi na pytania związane z jego treścią. Studenci zostali podzielni na cztery grupy: osoby czytające tekst z kartki A4, z 14-calowego laptopa, 6-calowego czytnika e-booków oraz 5-calowego telefonu komórkowego.

Wyniki i wnioski: Uzyskane wyniki dały podstawy, aby stwierdzić, że nośnik tekstu nie wpływa na sposób percepcji czytanej za jego pośrednictwem treści.

Zastosowanie praktyczne: Rezultaty badań mogą być wykorzystane w metodyce pracy nauczycieli akademickich.

Oryginalność/Wartość poznawcza: Innowacyjnością podejścia w badaniach zaprezentowanych $\mathrm{w}$ artykule jest zastosowanie eksperymentu w celu zebrania materiału poddanego następnie komparatystycznej analizie i interpretacji. W polskojęzycznej literaturze dotyczącej zagadnień recepcji tekstu takie podejście występuje rzadko.
\end{abstract}

\section{Słowa kluczowe}

Druk. Nośnik informacji. Percepcja tekstu. Urządzenie elektroniczne.

Otrzymany: 26 kwietnia 2018. Zrecenzowany: 29 maja 2018. Zaakceptowany: 17 lipca 2018.

\section{Wprowadzenie}

Celem artykułu jest przedstawienie wyników badań dotyczących percepcji i recepcji tekstu czytanego w wersji drukowanej oraz elektronicznej. Upowszechnienie technologii informacyjno-komunikacyjnych, czego odzwierciedleniem jest rosnąca dostępność do tekstów w cyfrowej formie, jak i zwiększająca się liczba urządzeń ułatwiających dostęp do elektronicznych zasobów tekstowych skłania do objęcia badaniami zachowań czytelniczych w kontekście ich zmian pod wpływem rosnącej popularności e-tekstów i ich nośników. Wśród podanych przez Polaków powodów korzystania z Internetu 58\% ogółu użytkowników cyfrowej przestrzeni wymieniło „czytanie, pobieranie gazet lub czasopism”. Większy wynik (57.8\%) zanotowano przy opcji „korzystanie z poczty elektronicznej” (GUS, 2017a, 2). Popularność prywatnej czynności polegającej na czytaniu prasy i innego typu 
tekstów w formie elektronicznej wynika między innymi z wzrastającego odsetka gospodarstw domowych mających dostęp do Internetu. W 2017 r. było to 81.9\%, o 10\% więcej niż w 2013 r. (GUS, 2017b, 115). Drugi czynnik wpływający na wybór sposobu korzystania z e-tekstów i stopień intensywności zapoznawania się z nimi wynika z rozwijających się technologii oraz dywersyfikacji usług dostępu do Internetu. Firmy telekomunikacyjne przygotowują zróżnicowane (biorąc pod uwagę cenę, szybkość przesyłania i ilość danych przesyłanych oraz odbieranych) oferty, co umożliwia potencjalnemu klientowi wybranie tej najlepiej odpowiadającej jego potrzebom. Z raportu za 2016 r. przygotowanego przez Urząd Komunikacji Elektronicznej wynika, że aż 87.5\% ankietowanych korzysta z telefonii komórkowej. Telefon komórkowy służy nie tylko do wykonywania połączeń telefonicznych, ale staje się też urządzeniem, za pośrednictwem którego użytkownicy coraz częściej łączą się z siecią. Według raportu było to $47.2 \%$ respondentów. Jednocześnie ci sami respondenci wskazywali na inne wykorzystywane rodzaje dostępu do Internetu - stacjonarny $(62.4 \%)$ i mobilny, ale za pośrednictwem innych niż telefon komórkowy urządzeń, na przykład tabletu czy smartfona (26.3\%) (Urząd..., 2016, 10).

Analiza struktury wiekowej użytkowników Internetu, czyli potencjalnych czytelników e-tekstu, wskazuje na nastolatków oraz studentów jako grupy najczęściej i najintensywniej łączące się z siecią. Młodzież w wieku od 15 do 19 lat deklaruje korzystanie z Internetu wiele razy dziennie lub cały czas, przede wszystkim w domu (80\%) i w szkole (39.2\%). Rzadziej korzystają z sieci u znajomych (32.4\%) czy w miejscach publicznych z dostępem wi-fi (29.7\%) (Pracownia..., 2017, 7). Najpopularniejszymi urządzeniami, za pomocą których łączą się z siecią jest telefon komórkowy oraz smartfon, następnie laptop, komputer stacjonarny i tablet (Pracownia..., 2017, 9). Wymieniane przez nastolatków główne powody korzystania z Internetu to chęć nawiązywania i podtrzymywania kontaktu z innymi e-użytkownikami, z czego wynika duża popularność serwisów społecznościowych i poszukiwanie rozrywki, a więc słuchanie muzyki i oglądanie filmów. Zasoby sieciowe są przez nastolatków postrzegane także jako pomoc w odrabianiu lekcji, jako źródło wiedzy w celu rozwijania pasji, hobby, a także jako źródło bieżących informacji (Pracownia..., 2017, 20). W podobny sposób z Internetu korzystają studenci (GUS, 2017b, 124). Wzrost liczby osób na całym świecie korzystających z Internetu, w przypadku młodych ludzi - młodzieży i studentów - sięgający $100 \%$, wielorakość form aktywności w sieci i różny stopień zaangażowania w interakcje w cyfrowej przestrzeni skłania badaczy do traktowania tych zjawisk jako przedmiotu analizy i interpretacji przy zastosowaniu metod i narzędzi charakterystycznych dla wielu dyscyplin naukowych. Jedno z zagadnień intrygujących do dzisiaj dotyczy różnic w percepcji oraz recepcji tekstu czytanego w wersji drukowanej i tego udostępnianego $\mathrm{w}$ formie elektronicznej. Upowszechnienie technologii mobilnej w komunikowaniu się, a także w korzystaniu z cyfrowych zasobów sieciowych wśród polskich użytkowników, szczególnie młodych osób, skłania też do postawienia pytań o sposób odczytywania tekstu udostępnianego na różnych nośnikach, w tym też na tradycyjnym (papierze) i prześledzenie ewentualnych różnic w percepcji tekstu między osobami posługującymi się konkretnymi nośnikami. Wiedza na temat stopnia przyswajalności tekstu przez pryzmat tak zwanego „efektu ekranu” ułatwiłaby na przykład przygotowywanie konkretnych wypowiedzi w formacie ułatwiającym lekturę, a przede wszystkim powodującym efektywniejsze zapoznawanie się i przyswajanie informacji. 


\section{Stan badań}

Amerykańscy badacze - Andrew Dillon, Cliff McKnight, John Richardson - w latach 80. i 90. XX w. w swoich pracach poruszali problematykę obejmującą różnice między czytaniem drukowanego tekstu a tego wyświetlanego na ekranie (Dillon, 1992). Przytaczali ustalenia będące odpowiedziami na pytania o szybkość, dokładność czytania, stopień zrozumienia tekstu, co niejednokrotnie sprowadzało się do konstatacji na temat wpływu urządzeń, czy raczej ich technicznych parametrów, na funkcjonowanie wzroku i tym samym na odbiór danej wypowiedzi (Dillon et al., 1993). Problematyka obejmująca satysfakcję użytkowników różnych elektronicznych urządzeń, za pośrednictwem których czyta się teksty, do dzisiaj nurtuje badaczy (Park et al., 2015; Köpper et al., 2016; Liu \& Huang, 2016). W miarę rozwiązywania technologicznych problemów, co ograniczało lub eliminowało niekorzystne dla człowieka czynniki warunkujące konkretny sposób czytania, zakres problematyki dotyczącej e-czytelnictwa podlegał rozszerzeniu. Analizowano metamorfozę praktyk i wyborów lekturowych przez pryzmat pojawienia się i upowszechnienia nowych, cyfrowych nośników tekstu. Innym obszarem badań były relacje między zmianami na rynkach wydawniczych (coraz bogatsza oferta e-booków, audiobooków), zachowaniami konsumenckimi i czytelniczymi oraz przeobrażeniami w funkcjonowaniu instytucji, na przykład bibliotek, chociażby w zakresie gromadzenia i udostępniania zbiorów (Kisilowska et al., 2016). W kręgu tematycznie zbliżonym do wyżej wspomnianych usytuowały się także rozważania nad funkcjonowaniem życia literackiego w sieci (Maryl, 2015) czy tworzeniem internetowych czytelniczych subkultur (Uliasz, 2010).

Jak już wspomniano, doskonalenie urządzeń i oprogramowania w znacznym stopniu zlikwidowało wiele niedogodności związanych z techniczną stroną korzystania z e-tekstów, co wykazali w badaniach między innymi Douglas, Kellami, Long, Hogetes, a w kilka lat po nich - Patty Wharten-Douglas. Z ustaleniami tych badaczy pokrywały się także wnioski Macieja Maryla po przeprowadzeniu eksperymentu mającego na celu zdiagnozowanie ewentualnych różnic w czytaniu drukowanego tekstu i jego cyfrowego odpowiednika (Maryl, 2011). Współcześni czytelnicy tekstów elektronicznych w mniejszym stopniu zwracają uwagę na problemy podnoszone przez pierwszych użytkowników (na przykład e-booków), czyli na: rozmiar ekranu, polaryzację, częstotliwość odświeżania, rozmieszczenie klawiszy nawigacyjnych czy czułość dotykowego ekranu. Owe kwestie natury technicznej ujmowane są dzisiaj w ramach zjawiska zmiany kontekstu prezentowania tekstu, zmiany zachodzącej pod wpływem cyfrowej metamorfozy wypowiedzi, a sprowadzającej się w uproszczeniu do zaniku cech ontologicznych drukowanego tekstu, co z kolei znajduje odzwierciedlenie w sposobie obcowania z nim - w jego percepcji i w dalszej kolejności recepcji. Badacze zauważyli zmiany jakościowe w czytaniu wynikające z zamiany tekstu drukowanego na elektroniczny. Lekturę e-tekstów charakteryzują jako „płytką, powierzchowną”, polegającą na przeglądaniu, skanowaniu i wychwytywaniu jedynie słów kluczowych. Środowisko cyfrowe nie sprzyja, zdaniem naukowców, refleksyjnemu czytaniu, wymagającemu spokoju i koncentracji (Hillesund, 2010). Konstatacja Andrew Walsha, że ludzie mają skłonności do unikania zapoznawania się z dłuższymi, skomplikowanymi tekstami na urządzeniach o małym ekranie, na przykład smartfonach czy telefonach komórkowych, koreluje z obawami o wyniki w nauce młodych osób, które, wychowane w cyfrowym świecie, są online praktycznie całą dobę (Walsh, 2012; Joon \& Joan, 2013). W związku z tym wskazuje się na 
konieczność kontynuowania badań zarówno nad percepcją, jak i recepcją tekstów, biorąc pod uwagę nie tylko zewnętrzne okoliczności lektury, osobiste potrzeby i kompetencje użytkowników, ale także wybór urządzenia cechującego się określoną wielkością ekranu. Postawione hipotezy zakładają bowiem istnienie zależności między odbiorem tekstu a, na przykład, wielkością ekranu służącego do jego wyświetlania (Liu \& Huang, 2016).

\section{Przebieg badań}

Przygotowano eksperyment, którego celem było zbadanie percepcji tekstu w formie drukowanej i elektronicznej, aby wskazać ewentualne różnice w stopniu zapamiętania i zrozumienia czytanej wypowiedzi ze względu na formę udostępniania. Postawiono zatem następujące pytanie badawcze: Czy nośnik tekstu wpływa na jego percepcję?

\subsection{Próba}

Badaniami objęto studentów kierunku informacja naukowa i bibliotekoznawstwo Uniwersytetu Śląskiego na poziomie pierwszym, czyli trzy roczniki. Łącznie przebadano 70 osób (60 kobiet, 9 mężczyzn, 1 osoba wpisała płeć „inna”). Wybór próby celowej został podyktowany zakresem projektu, dla którego inspiracją była przede wszystkim obserwacja zachowań studentów na zajęciach poświęconych między innymi dyskusji na temat zalecanej literatury. Można bowiem zauważyć, że coraz więcej studentów korzysta z tekstów za pośrednictwem laptopów, smartfonów, telefonów, także w sytuacji funkcjonowania wypowiedzi tylko w formie tradycyjnej (druk). Dodatkowym impulsem były również wyniki badań czytelnictwa uwzględniające recepcję wypowiedzi udostępnianych w formie cyfrowej. Badaniami objęto studentów tylko pierwszego poziomu, ponieważ założono, że nabyte przez nich na wcześniejszym etapie edukacji kompetencje z zakresu wiedzy, umiejętności i postawy społecznej są podobne, co pozwala na traktowanie tej grupy, w odróżnieniu od studentów poziomu drugiego, jako w miarę jednorodnej. Nie wyklucza się w innym czasie przeprowadzenia badań także grupy z poziomu drugiego oraz studentów innych kierunków, ale projekt taki wymagałyby uwzględnienia dodatkowych zmiennych i modyfikacji kwestionariusza ankiety.

\subsection{Narzędzia}

W eksperymencie użyto:

(1) Tekst wyabstrahowany z publikacji Hanny Kirchner pod tytułem Nałkowska albo życie pisaniem wydawnictwa W.A.B z 2011 r. Wybrana książka wyszła w serii „Fortuna i Fatum", w ramach której ogłaszane są biografie popularnonaukowe. Wybór tej publikacji został podyktowany następującymi kryteriami:

a. charakter (przynależność gatunkowa) publikacji - popularnonaukowe opracowanie, w którym język literacki posłużył przekazaniu informacji faktograficznych. Założono, że wybór tego rodzaju tekstu, sytuującego się, ze względu na język i organizację treści, między literackimi publikacjami (głównie o funkcji ludycznej) a naukowymi opracowaniami, nie będzie przekraczał kompetencji czytelniczych badanych osób; 
b. autor - autorka, Hanna Kirchner to historyk literatury, zdaniem krytyków rzetelnie i ze znawstwem opracowująca swoje biograficzne publikacje, w tym tę poświęconą Nałkowskiej;

c. temat - uwagę skierowano na biografię pisarki, z twórczością której współcześni uczniowie niekoniecznie musieli się zetknąć na wcześniejszych etapach edukacji, ale której nazwisko nie jest dla nich anonimowe.

Tekst obejmował informacje faktograficzne dotyczące trzech utworów Nałkowskiej: Granicy, Niecierpliwych i Medalionów. Liczył 3681 znaków (482 wyrazy). Nie był zatem długi - zajął jedną stronę A4, przy zachowaniu standardowej wielkości czcionki, marginesów, odstępów między wersami. Uwzględniono podział tekstu na akapity zgodny z oryginałem. Tekst przeformatowano (zachowano te same parametry), aby udostępnić go w elektronicznej formie na następujących urządzeniach: (1) Laptop Lenovo IdeaPad 100s; ekran 14 cali; (2) Amazon Kindle 6 cali (niepodświetlany); (3) Telefon Sony Xperia Z1; 5 cali (telefon był obrócony w pozycji horyzontalnej, aby zmieściło się więcej tekstu w jednej linii).

Respondenci losowo wybierali nośnik tekstu, przy czym starano się, aby z tekstem udostępnionym na każdym nośniku zapoznało się tyle samo osób w danym roczniku (odstępstwa dotyczyły grup nieparzystych).

(2) Kwestionariusz ankiety, wypełniany przez wszystkich uczestniczących w badaniach. Kwestionariusz składał się z pięciu pytań metryczki (płeć, rok studiów, typ ukończenia szkoły ponadgimnazjalnej, miejsce aktualnego zamieszkania, dysponowanie własnymi dochodami), części głównej (Załącznik 1), którą tworzyło 12 pytań (pięć zamkniętych, osiem otwartych) dotyczących konkretnych kwestii odnoszących się do trzech wymienionych w czytanym fragmencie książek Nałkowskiej, oraz otwartego pytania końcowego, w którym poproszono respondentów o podzielenie się uwagami dotycząymi ewentualnych technicznych trudności w korzystaniu z elektronicznej wersji tekstu. Kwestionariusz wypełniano po zapoznaniu się z tekstem.

\section{Analiza wyników}

W literaturze psychologicznej i pedagogicznej, a także bibliologicznej istnieje wiele definicji terminu czytanie, przy czym większość z nich określa ten proces jako złożony i dynamiczny, na który składają się zjawiska fizyczne, fizjologiczne i psychologiczne. Według Eve Malmquist (1982) oraz Anny Brzezińskiej (Brzezińska \& Burtowy, 1985) czytanie to wieloczynnościowa aktywność wymagająca współdziałania analizatorów w przebiegu procesów myślowych, które odpowiedzialne są za analizę i syntezę informacji, ich przetworzenie i kojarzenie z wcześniejszym doświadczeniem. Jednym z komponentów czytania jest percepcja (postrzeganie, spostrzeganie), a więc rozpoznawanie grafemów, fonemów w kontekście rozumienia poszczególnych wyrazów i dalej większych partii wypowiedzi oraz ich zapamiętywania.

Przeprowadzone badania dotyczyły tak rozumianej percepcji i miały za zadanie wychwycenie różnic w stopniu zapamiętania treści w zależności od formy udostępniania wypowiedzi. W części zasadniczej kwestionariusza 11 pytań odnosiło się bezpośrednio do informacji zawartych w tekście. Pytanie 12. wymagało od czytającego wykorzystania 
wiedzy nabytej w szkole ponadgimnazjalnej, na przykład z zakresu stylistyki. Odpowiedziom przypisano wartości liczbowe od 0 do 3 odzwierciedlające stopień poprawności (zapamiętania informacji z czytanego tekstu): 0 punktów odpowiadało odpowiedzi błędnej; 1 punkt to odpowiedź dostateczna; 2 punkty to odpowiedź dobra; 3 punkty to odpowiedź bardzo dobra.

Uzyskane wyniki dały podstawy, aby zaprzeczyć tezie o wpływie nośnika tekstu na jego percepcję nośnika tekstu na percepcję tekstu.

Biorąc pod uwagę czas przeznaczony na zapoznanie się z tekstem, nie odnotowano znaczących różnic między osobami korzystającymi z konkretnych nośników (zob. Tab. 1).

Tab. 1. Średni czas zapoznawania się z tekstem wszystkich respondentów

\begin{tabular}{|l|c|c|}
\hline \multicolumn{1}{|c|}{ Rodzaj nośnika } & Liczba użytkowników & Średni czas* \\
\hline Druk A4 & 19 & 2.80 \\
\hline Kindle & 18 & 3.38 \\
\hline Laptop & 16 & 2.99 \\
\hline Telefon & 17 & 3.13 \\
\hline *W całym eksperymencie czas mierzono w minutach i setnych częściach minuty. \\
\hline
\end{tabular}

Wynik 2.8 min. wskazuje na druk jako formę, która pozwalała najszybciej zapoznać się z tekstem. Trzeba jednak od razu zaznaczyć, że w poszczególnych rocznikach studentów uzyskane wyniki nie potwierdziły jakoby tradycyjna forma decydowała o szybkości czytania. Wyniki te zostaną szczegółowo omówione dalej. Przy czytaniu drukowanego tekstu wskaźniki szybkości czytania mieściły się w zakresie od 1.39 min do $5.0 \mathrm{~min}$. Tekst elektroniczny najszybciej czytano, korzystając z laptopa (średni czas -2.99 min, a wyniki skrajne to 1.49 min i 5.17 min. Nieco wolniej operowano telefonem - średni czas wyniósł 3.13 min. Najszybciej polecony fragment przeczytano, korzystając z tego urządzenia w czasie 2.04 min, najdłużej czytanie zajęło 4.42 min. Najmniej przyjaznym urządzeniem pod względem długości czasu przeznaczonego na czytanie okazał się czytnik Kindle. Średni czas to $3.38 \mathrm{~min}$ (najszybciej przeczytano tekst na Kindle’u w $1.20 \mathrm{~min}$, najdłużej w $6.13 \mathrm{~min}$ ). Omawiane wartości prezentuje rysunek 1 . W poszczególnych rocznikach studentów, podobnie jak w przypadku tekstu drukowanego, rozkład wyników odzwierciedlających szybkość zapoznawania się z tekstem elektronicznym świadczył o preferencji różnych urządzeń. Nie zawsze wybór laptopa oznaczał najkrótszy czas czytania.

Biorąc pod uwagę kolejne roczniki studentów, nie odnotowano większych różnic w tym parametrze. Studenci pierwszego roku najdłużej zapoznawali się z tekstem udostępnianym w telefonie (średni czas - $3.31 \mathrm{~min}$ ) (zob. Tab. 2). Najwyższy wskaźnik w tej podgrupie to 4.19 min, najniższy 2.04. Najszybciej czytali tekst za pośrednictwem laptopa (średni czas to $2.06 \mathrm{~min}$, a wyniki wahały się od $1.49 \mathrm{~min}$ do $2.26 \mathrm{~min}$ ). Szybciej niż z telefonu komórkowego czytano tekst z czytnika Kindle (średni czas - 3.19 min), jeszcze szybciej w formie drukowanej (średni czas - 3.04 min). Porównując najlepsze czasy czytania tekstu elektronicznego i drukowanego wśród studentów pierwszego roku, uzyskujemy: 1.49 min (laptop) i 2.05 min (druk). 


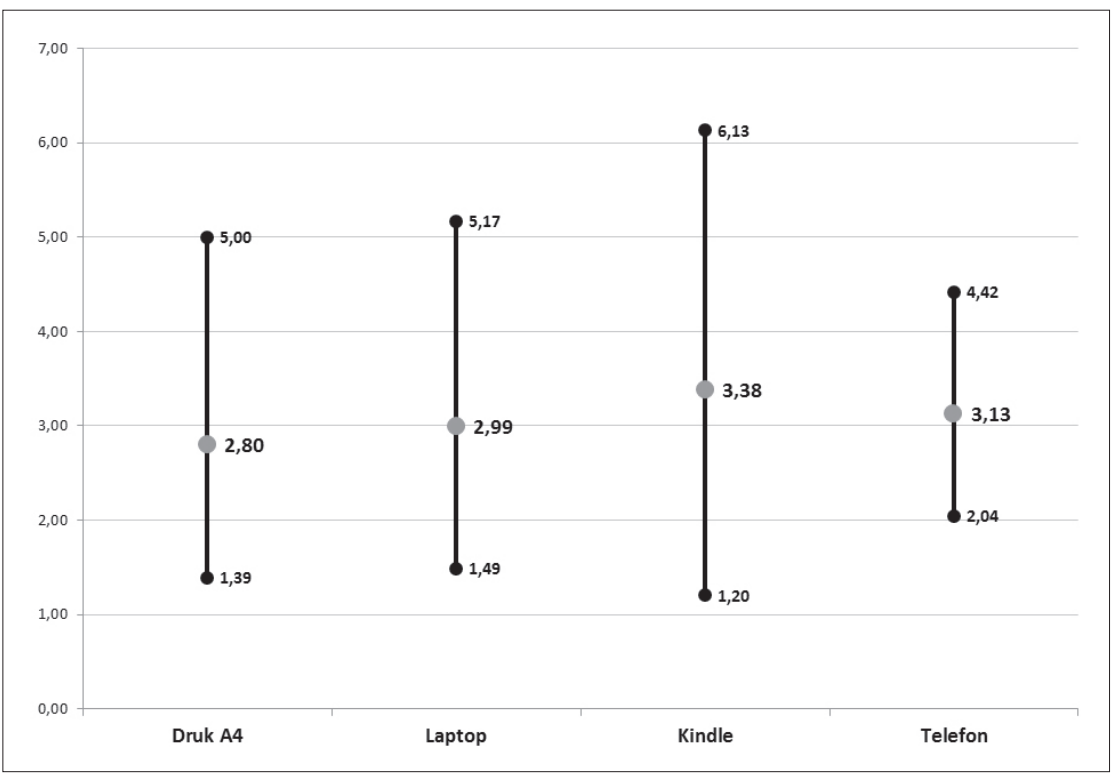

Rys. 1. Czas czytania tekstu (minimalny, średni, maksymalny)

Tab. 2. Średni czas zapoznawania się z tekstem studentów pierwszego roku

\begin{tabular}{|l|c|c|c|}
\hline Rodzaj nośnika & Liczba użytkowników & Średni czas & Średnia punktów \\
\hline Druk A4 & 7 & 3.04 & 9.3 \\
\hline Kindle & 6 & 3.19 & 8.2 \\
\hline Laptop & 5 & $2.06 *$ & 7 \\
\hline Telefon & 6 & 3.31 & 10.5 \\
\hline * jedna osoba przeczytała w rekordowym czasie 1.49, co wyraźnie zaważyło na średniej \\
\hline
\end{tabular}

Tab. 3. Średni czas zapoznawania się z tekstem studentów drugiego roku

\begin{tabular}{|l|c|c|c|}
\hline \multicolumn{1}{|c|}{ Rodzaj nośnika } & Liczba użytkowników & Średni czas & Średnia punktów \\
\hline Druk A4 & 7 & 2.32 & 13.3 \\
\hline Kindle & 7 & $3, .67$ & 9 \\
\hline Laptop & 7 & 3.52 & 8.7 \\
\hline Telefon & 6 & 3.04 & 8.3 \\
\hline
\end{tabular}

Wyniki dotyczące czasu czytania uzyskane przez studentów drugiego roku jeszcze wyraźniej wskazują brak korelacji między czasem zapoznawania się z tekstem a jego nośnikiem (zob. Tab. 3). Z tekstem w formie elektronicznej najszybciej zapoznawano się, korzystając z telefonu (średni czas wyniósł 3.04 min, a wartości skrajne to $2.05 \mathrm{~min}$ i $4.42 \mathrm{~min}$ ). Najwolniej czytano tekst z Kindle'a: średni czas - $3.67 \mathrm{~min}$ (od $1.20 \mathrm{~min}$ do $6.13 \mathrm{~min}$ ). Niewiele szybciej przebiegała percepcja przy korzystaniu z laptopa (średni czas - 3.52 min, 
a wartości skrajne wahają się od $2.15 \mathrm{~min}$ do $5.17 \mathrm{~min}$ ). Dla studentów drugiego roku, biorąc pod uwagę czas, najlepszą formę udostępniania tekstu okazał się druk: średni czas wyniósł 2,32 min. Najszybciej przeczytano fragment w czasie $1.39 \mathrm{~min}$, natomiast wynik 2.43 min był najwyższy w tej grupie.

Tab. 4. Średni czas zapoznawania się z tekstem studentów trzeciego roku

\begin{tabular}{|l|c|c|c|}
\hline \multicolumn{1}{|c|}{ Rodzaj nośnika } & Liczba użytkowników & Średni czas & Średnia punktów \\
\hline Druk A4 & 5 & 3.12 & 12.2 \\
\hline Kindle & 5 & 3.19 & 10.6 \\
\hline Laptop & 4 & 3.23 & 9.5 \\
\hline Telefon & 5 & 3.01 & 13.6 \\
\hline
\end{tabular}

Z kolei studenci trzeciego roku najszybciej czytali tekst z telefonu (średni czas - 3.01 min, wartości skrajne to: 2.55 min i $3.47 \mathrm{~min}$. Średni czas $3.12 \mathrm{~min}$ (skrajne wartości: $2.23 \mathrm{~min}$ i $3.58 \mathrm{~min}$ ) wskazał druk jako formę, w której tekst czytano nieco wolniej. Jeszcze wolniej zapoznawano się z tekstem udostępnianym na Kindle’u (średni czas - 3.19 min, a wartości skrajne wyniosły: 2.15 min i 4 min). Najmniej przyjazny pod względem czasu czytania okazał się laptop (średni czas - 3.23 min, wartości skrajne: 3.11 min i $3.38 \mathrm{~min}$ ) (zob. Tab. 4).

Na czas, w jakim zapoznano się z tekstem, mogły mieć wpływ różne czynniki, w tym właściwości techniczne urządzeń, za pośrednictwem których czytano wypowiedź. Niektórzy studenci zgłaszali uwagi (13. pytanie kwestionariusza) na temat utrudnień technicznych, wśród których najczęściej wymieniano:

W odniesieniu do Kindle'a:

(1) rozmiar ekranu (mały ekran);

(2) zmęczenie oczu;

(3) problemy z koncentracją;

(4) problemy z obsługą (przeznaczenie przycisków, obawa przed zniszczeniem).

W odniesieniu do laptopa:

(1) stopień jasności ekranu;

(2) zmęczenie oczu.

W odniesieniu do telefonu:

(1) czas wyświetlania ekranu;

(2) czułość dotykowego ekranu (bezwiednie zaznaczanie fragmentów tekstu);

(3) rozmiary ekranu (mały, konieczność przewijania tekstu, mały rozmiar czcionki).

Część respondentów akcentowała zalety lektury przy wykorzystaniu wspomnianych urządzeń. Pozostawienie tego pytania bez odpowiedzi również można uznać za przejaw pozytywnego stosunku do czytania tekstu w wersji elektronicznej. Najwięcej krytycznych uwag dotyczyło korzystania z telefonu komórkowego. Wszyscy respondenci (17 osób) czytający tekst na tym urządzeniu wskazywali na jakieś utrudnienia. Porównując, wśród użytkowników Kindle’a krytyczne sądy wypowiedziało pięć z 18 osób, a na 16 czytających na laptopie takie uwagi zgłosiło także pięć osób. Owe wypowiedzi dały podstawy dla wniosku, że wielkość powierzchni, na jakiej umieszczono tekst (wielkość ekranu), a w konsekwencji rozmiar czcionki czy ilość tekstu dostępna bez ingerowania w funkcjonowanie urządzenia ma wpływ na komfort obcowania z tekstem, czyli też na jego percepcję. Należy 
także wspomnieć o innych uwarunkowaniach lektury, niezwiązanych ze stroną techniczną urządzeń elektronicznych, które podnosili respondenci. Według nich negatywnie na odbiór wpływały: zewnętrzne okoliczności, jak na przykład szum, rozmowy prowadzone przez innych badanych w trakcie eksperymentu; indywidualne przyzwyczajenia; poziom kompetencji, także w odniesieniu do innych czytanych tekstów (na przykład podkreślano zbyt duży stopień skomplikowania przedstawionego tekstu, co w odczuciu respondenta kwalifikowało wypowiedź do „niezrozumiałych i nielogicznych”).

Wśród wszystkich respondentów najwyższa średnia punktów cechuje czytających e-tekst przy wykorzystaniu telefonu komórkowego (10.8 pkt), co zaskakuje, biorąc pod uwagę liczbę czy rodzaj krytycznych uwag zgłaszanych co do komfortu korzystania z tego urządzenia i skłania do zastanowienia się nad rzeczywistym wpływem technicznych parametrów urządzenia na percepcję. W poszczególnych rocznikach można także zauważyć, że grupy osób operujących telefonem uzyskały najwyższe średnie (dwa roczniki - pierwszy i trzeci - na trzy przebadane). Różnica ( 0.8 pkt) między średnimi osób korzystających z Kindle'a i laptopa jest niewielka. Średnia punktów czytających tekst udostępniony na Kindle’u wynosi 9.2, na laptopie 8.4. Różnice w poszczególnych rocznikach są zbliżone do 1 punktu. W odniesieniu do tekstu drukowanego średnia uzyskanych punktów wynosi 11.5, co skłania do uznania tej formy za najbardziej komfortową i sprzyjającą lekturze przynoszącej najlepsze wyniki. Trzeba jednak uwzględnić inny rozkład tej wartości w poszczególnych rocznikach. Jeden na trzy roczniki (drugi rok) uzyskał najwyższą średnią punktów, czytając tekst w wersji drukowanej. W pozostałych rocznikach średnie dla tej zmiennej plasowały się na drugim miejscu.

Analiza liczby punktów przypisanych odpowiedziom na poszczególne pytania nie pozwala na potwierdzenie istnienia korelacji między typem nośnika a stopniem zapamiętania tekstu. Uzyskane dane skłaniają raczej do upatrywania innych przyczyn decydujących o stopniu percepcji tekstu.

Najwięcej punktów, bez względu na rocznik, badani uzyskali, odpowiadając na pytanie nr 1 (łącznie 180 pkt, pierwszy rok - 56 pkt; drugi rok - 70 pkt; trzeci rok - 54 pkt) i pytanie nr 2 (łącznie 110 pkt, pierwszy rok - 36 pkt; drugi rok - 40 pkt; trzeci rok - 34 pkt). Wysokie wyniki dały także odpowiedzi na pytanie nr 8 (łącznie 93 pkt, w tym pierwszy rok - 29 pkt, drugi rok - 34 pkt, trzeci rok - 30 pkt), na pytanie nr 7 (łącznie 86 pkt, pierwszy rok - 30 pkt, drugi rok - 35 pkt, trzeci rok - 21 pkt) i na pytanie nr 4 (łącznie 69 pkt, pierwszy rok - 20 pkt, drugi rok - 29 pkt, trzeci rok - 20 pkt). Punktację dla poszczególnych roczników za odpowiedzi na powyższe pytania przez pryzmat zmiennej nośnik tekstu przedstawiają tabele 5-9.

Tab. 5. Liczba punktów uzyskanych przez respondentów na pytanie nr 1

\begin{tabular}{|l|c|c|c|c|}
\hline \multicolumn{1}{|c|}{ Pytanie 1 } & I rok & II rok & III rok & Suma \\
\hline Tekst drukowany A4 & 19 & 19 & 14 & 52 \\
\hline Laptop & 8 & 16 & 11 & 35 \\
\hline Kindle & 15 & 17 & 14 & 46 \\
\hline Telefon & 14 & 18 & 15 & 47 \\
\hline Suma & 56 & 70 & 54 & 180 \\
\hline
\end{tabular}


Tab. 6. Liczba punktów uzyskanych przez respondentów na pytanie nr 2

\begin{tabular}{|l|c|c|c|c|}
\hline \multicolumn{1}{|c|}{ Pytanie 2 } & I rok & II rok & III rok & Suma \\
\hline Tekst drukowany A4 & 10 & 9 & 6 & 25 \\
\hline Laptop & 6 & 11 & 9 & 26 \\
\hline Kindle & 10 & 13 & 8 & 31 \\
\hline Telefon & 10 & 7 & 11 & 28 \\
\hline Suma & 36 & 40 & 34 & 110 \\
\hline
\end{tabular}

Tab. 7. Liczba punktów uzyskanych przez respondentów na pytanie nr 4

\begin{tabular}{|l|c|c|c|c|}
\hline \multicolumn{1}{|c|}{ Pytanie 4 } & I rok & II rok & III rok & Suma \\
\hline Tekst drukowany A4 & 4 & 8 & 6 & 18 \\
\hline Laptop & 5 & 9 & 4 & 18 \\
\hline Kindle & 6 & 7 & 4 & 17 \\
\hline Telefon & 5 & 5 & 6 & 16 \\
\hline Suma & 20 & 29 & 20 & 69 \\
\hline
\end{tabular}

Tab. 8. Liczba punktów uzyskanych przez respondentów na pytanie nr 7

\begin{tabular}{|l|c|c|c|c|}
\hline \multicolumn{1}{|c|}{ Pytanie 7 } & I rok & II rok & III rok & Suma \\
\hline Tekst drukowany A4 & 9 & 10 & 6 & 25 \\
\hline Laptop & 5 & 7 & 5 & 17 \\
\hline Kindle & 5 & 10 & 5 & 20 \\
\hline Telefon & 11 & 8 & 5 & 24 \\
\hline Suma & 30 & 35 & 21 & 86 \\
\hline
\end{tabular}

Tab. 9. Liczba punktów uzyskanych przez respondentów na pytanie nr 8

\begin{tabular}{|l|c|c|c|c|}
\hline \multicolumn{1}{|c|}{ Pytanie 8 } & I rok & II rok & III rok & Suma \\
\hline Tekst drukowany A4 & 11 & 11 & 9 & 31 \\
\hline Laptop & 4 & 10 & 4 & 18 \\
\hline Kindle & 6 & 7 & 9 & 22 \\
\hline Telefon & 8 & 6 & 8 & 22 \\
\hline Suma & 29 & 34 & 30 & 93 \\
\hline
\end{tabular}

Porównanie wyników nie wskazało na to, aby konkretny nośnik miał wpływ na uzyskany wynik, a więc sumę punktów. Nie można zauważyć, żeby przewagę w udzielaniu prawidłowych odpowiedzi zyskały osoby czytające drukowany tekst, chociaż w przypadku tego nośnika dużo odpowiedzi na pytania nr 1-2, 4 oraz 7-8 punktowano maksymalnie. Punktację 
maksymalną otrzymywały jednak także osoby korzystające z wersji elektronicznych. Suma punktów uzyskanych przez studentów drugiego i trzeciego roku odpowiadających na pytanie nr 2 sugeruje nawet skuteczniejsze przyswojenie przez nich informacji z tekstów w elektronicznej wersji (za pośrednictwem telefonu komórkowego) niż drukowanej. Różnice w percepcji elektronicznych wersji tekstu w odniesieniu do owych pięciu pytań są jeszcze mniej zauważalne niż w przypadku zestawienia ze sobą wyników odbioru tekstów elektronicznego i drukowanego. Różnice te mieszczą się bowiem w przedziale od 1 do 7 punktów, przy czym najczęściej wynoszą od 1 do 3 punktów. Trudno odnaleźć tutaj prawidłowość tłumaczącą uzyskane wyniki, które następnie można byłoby interpretować na „korzyśćc konkretnego nośnika. Sumy uzyskanych punktów w pytaniach 1-2 i 8 (1. Pytanie - 35 pkt; 2. Pytanie - 26 pkt; 8 . Pytanie - 18 pkt) wskazywałyby na gorszą, niż w przypadku Kindle'a i telefonu, przyswajalność tekstu udostępnianego na laptopie. Jednak, porównując wyniki z pytań nr 2, 4 i 8 uzyskane przez studentów drugiego roku czytających tekst z laptopa i telefonu, komputer okazuje się urządzeniem sprzyjającym zapamiętaniu większej liczby informacji. Zestawiając z kolei sumy punktów za odpowiedzi wszystkich respondentów z pytań nr 1-2 i 7-81, można dojść do wniosku, że lektura tekstu z telefonu komórkowego, mimo zgłaszanych zastrzeżeń, pozwoliła na udzielanie odpowiedzi wysoko punktowanych.

Najwięcej punktów studenci uzyskali, odpowiadając na pytania zamknięte a więc nr 1-2, 4 i 7-8. Powyżej przeciętnej dały odpowiedzi jeszcze tylko na jedno - pytanie nr 3 (zob. Tab. 10). Tym razem było to pytanie otwarte. Najlepiej, bez względu na rocznik, odpowiadały na nie osoby czytające tekst drukowany (łącznie uzyskały 21 punktów, pierwszy rok - 6 pkt, drugi rok -6 pkt, trzeci rok - 9 pkt), co jednak nie oznaczało, że korzystający z innych nośników niż druk na papierze nie udzielali poprawnych odpowiedzi. Na trzecim roku wśród osób czytających za pośrednictwem Kindle’a znalazło się dwie na pięć, które uzyskały maksymalną liczbę punktów, a wśród korzystających z laptopa i telefonu - po jednej osobie.

Tab. 10. Liczba punktów uzyskanych przez respondentów na pytanie nr 3

\begin{tabular}{|l|c|c|c|c|}
\hline \multicolumn{1}{|c|}{ Pytanie 3 } & I rok & II rok & III rok & Suma \\
\hline Tekst drukowany A4 & 6 & 6 & 9 & 21 \\
\hline Laptop & 3 & 3 & 3 & 9 \\
\hline Kindle & 3 & 6 & 6 & 15 \\
\hline Telefon & 0 & 0 & 3 & 3 \\
\hline Suma & 12 & 15 & 21 & 48 \\
\hline
\end{tabular}

Analiza wyników odnoszących się do pozostałych pytań otwartych (nr 5-6 i 9-12) również nie pozwala jednoznacznie stwierdzić, który nośnik sprzyja efektywniejszemu zapamiętywaniu tekstu, chociaż można zauważyć, że osoby korzystające z drukowanego tekstu uzyskiwały większą liczbę punktów niż te obcujące z e-tekstem (zob. Tab. 11-14). W grupie czytających za pośrednictwem urządzenia elektronicznego najpoprawniej na otwarte pytania

1 Przy pytaniu 4., mimo że suma punktów uzyskanych przez wszystkie osoby czytające tekst z telefonu była w porównaniu z sumami przypisanymi innym nośnikom najniższa, tylko dwie osoby z tej grupy (na siedemnaście) nie udzieliły poprawnej odpowiedzi na pytanie. 
odpowiadali użytkownicy telefonów. Uzyskiwali oni najlepsze wyniki bez względu na rocznik. Trudno natomiast wykryć jakąś prawidłowość w przypadku użytkowników Kindle’a i laptopa. Na pytanie 6. czytający z Kindle’a w sumie zdobyli tyle samo punktów co użytkownicy telefonu. Studentom, którzy wylosowali laptop, na to samo pytanie można było przypisać w sumie tylko 4 punkty. Natomiast na pytania 9 i 11 czytający z laptopa odpowiadali lepiej od osób używających Kindle’a.

Tab. 11. Liczba punktów uzyskanych przez respondentów na pytanie nr 5

\begin{tabular}{|l|c|c|c|c|}
\hline \multicolumn{1}{|c|}{ Pytanie 5 } & I rok & II rok & III rok & Suma \\
\hline Tekst drukowany A4 & 0 & 9 & 0 & 9 \\
\hline Laptop & 0 & 3 & 0 & 3 \\
\hline Kindle & 1 & 0 & 3 & 4 \\
\hline Telefon & 4 & 2 & 5 & 11 \\
\hline Suma & 5 & 14 & 8 & 27 \\
\hline
\end{tabular}

Tab. 12. Liczba punktów uzyskanych przez respondentów na pytanie nr 6

\begin{tabular}{|l|c|c|c|c|}
\hline \multicolumn{1}{|c|}{ Pytanie 6 } & I rok & II rok & III rok & Suma \\
\hline Tekst drukowany A4 & 4 & 6 & 8 & 18 \\
\hline Laptop & 0 & 2 & 2 & 4 \\
\hline Kindle & 1 & 2 & 4 & 7 \\
\hline Telefon & 3 & 1 & 3 & 7 \\
\hline Suma & 8 & 11 & 17 & 36 \\
\hline
\end{tabular}

Tab. 13. Liczba punktów uzyskanych przez respondentów na pytanie nr 9

\begin{tabular}{|l|c|c|c|c|}
\hline \multicolumn{1}{|c|}{ Pytanie 9 } & I rok & II rok & III rok & Suma \\
\hline Tekst drukowany A4 & 0 & 12 & 0 & 12 \\
\hline Laptop & 3 & 0 & 0 & 3 \\
\hline Kindle & 2 & 0 & 0 & 2 \\
\hline Telefon & 7 & 0 & 5 & 12 \\
\hline Suma & 12 & 12 & 5 & 29 \\
\hline
\end{tabular}

W pytaniu nr 10 żaden z roczników nie zdobył ani jednego punktu.

Tab. 14. Liczba punktów uzyskanych przez respondentów na pytanie nr 11

\begin{tabular}{|l|c|c|c|c|}
\hline \multicolumn{1}{|c|}{ Pytanie 11 } & I rok & II rok & III rok & Suma \\
\hline Tekst drukowany A4 & 0 & 0 & 1 & 1 \\
\hline Laptop & 1 & 0 & 0 & 1 \\
\hline Kindle & 0 & 0 & 0 & 0 \\
\hline Telefon & 1 & 2 & 1 & 4 \\
\hline Suma & 2 & 2 & 2 & 6 \\
\hline
\end{tabular}


Tab. 15. Liczba punktów uzyskanych przez respondentów na pytanie nr 12

\begin{tabular}{|l|c|c|c|c|}
\hline \multicolumn{1}{|c|}{ Pytanie 12 } & I rok & II rok & III rok & Suma \\
\hline Tekst drukowany A4 & 2 & 3 & 2 & 7 \\
\hline Laptop & 0 & 0 & 0 & 0 \\
\hline Kindle & 0 & 1 & 0 & 1 \\
\hline Telefon & 0 & 4 & 6 & 10 \\
\hline Suma & 2 & 8 & 8 & 18 \\
\hline
\end{tabular}

\section{Dyskusja}

Badania chińskich naukowców (Liu \& Huang, 2016) dowiodły, że studenci preferowali czytanie tekstów drukowanych, zwłaszcza tych o większej objętości, obojętnie czy były to materiały służące nauce (podręczniki), czy na przykład literatura piękna. Do podobnych wniosków doszła Jolanta Laskowska, która zainteresowała się wpływem nośnika tekstu na czytelnictwo studentów kierunków humanistycznych w Gdańsku (Laskowska, 2017). Wśród powodów zniechęcających do sięgania po e-teksty zarówno polscy, jak i chińscy studenci wymieniali między innymi: uciążliwości natury technicznej (budowa urządzeń, za pośrednictwem których czytali wypowiedź, na przykład mały ekran); koszty, na przykład zakupu urządzenia, ale także przywiązanie do tradycyjnej formy - książki drukowanej. Podobnego typu uwagi, dotyczące parametrów przenośnych elektronicznych urządzeń służących do odczytu tekstów, zgłaszali studenci poddani temu eksperymentowi.

Nadal więc, mimo licznych rozwiązań pozwalających użytkownikowi dostosowywać parametry urządzeń do własnych indywidualnych potrzeb, obsługiwanie sprzętu elektronicznego nie musi być komfortowe i bezproblemowe. Czy problemy natury technologicznej mają bezpośredni wpływ na jakość lektury przejawiającą się w stopniu zapamiętania informacyjnej warstwy tekstu? Liczne badania wykazują negatywne konsekwencje preferowania e-tekstu i zepchnięcia na margines czytania książek drukowanych. Zdaniem badaczy uczniowie, którzy przedkładali wypowiedzi cyfrowe nad druk, mieli gorsze wyniki w nauce (Hayles, 2010). Przyczyn takiego stanu rzeczy upatruje się między innymi w nawykach, jakie kształtuje sama budowa urządzeń elektronicznych i ich oprogramowanie. Użytkowanie laptopa, a szczególnie tabletu, telefonu komórkowego czy smartfona w celach komunikacyjnych oraz rozrywkowych utrwala przyzwyczajenia skłaniające do określonego typu lektury - przyjemnej, szybkiej, niewymagającej namysłu czy refleksji. Przeprowadzony eksperyment z udziałem studentów informacji naukowej i bibliotekoznawstwa Uniwersytetu Śląskiego dowiódł jednak braku istotnych różnic w percepcji drukowanego tekstu i jego cyfrowego odpowiednika. Respondenci wprawdzie zgłaszali więcej zastrzeżeń co do komfortu korzystania z urządzeń, za pośrednictwem których czytali tekst, ale niedogodności te nie wpłynęły w znaczący sposób na czas potrzebny do zapoznania się z wypowiedzią ani na stopień zapamiętania informacji w niej zawartych. Niektórzy studenci osiągali lepsze wyniki, posługując się na przykład telefonem komórkowym, od osób czytających druk (trzeci rok studiów). Ci sami również szybciej zapoznali się z tekstem z telefonu. Inaczej, na korzyść tradycyjnego druku, sytuacja wyglądała wśród uczących się na pierwszym roku. Trudno 
zatem mówić o bezpośrednim wpływie okoliczności lektury (używanego urządzenia) na odbiór czytanego tekstu² ${ }^{2}$ Rodzaj elektronicznego urządzenia losowanego przez studentów Uniwersytetu Śląskiego w trakcie eksperymentu nie warunkował stopnia percepcji czytanego tekstu. Nie można, na podstawie uzyskanych wyników, wskazać na związek między użytym podczas lektury urządzeniem a liczbą uzyskanych punktów, odzwierciedlających poziom opanowania tekstu (Rys. 2).

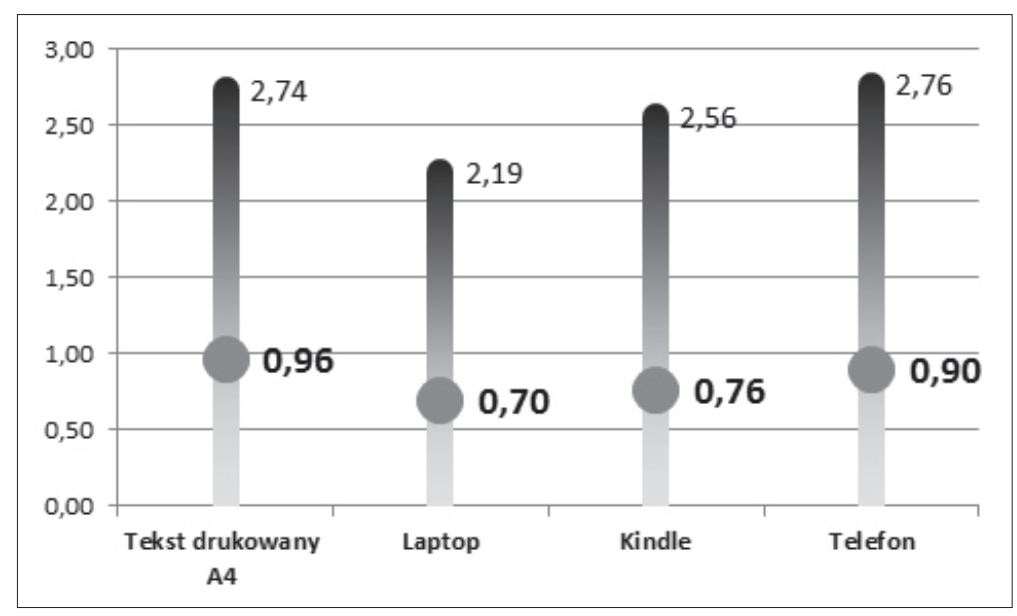

Rys. 2. Średnia liczba punktów uzyskanych za wszystkie odpowiedzi

Studenci pierwszego i trzeciego roku czytający z telefonu uzyskiwali najwyższą średnią punktów wśród osób posługujących się elektronicznymi urządzeniami. Natomiast na drugim roku lepiej wypadli używający Kindle'a. Czy zatem obawy, związane z preferowaniem przez młodych ludzi czytania o charakterze powierzchownym, tak zwanego „skanowania”, mającego wpływ na wyniki w nauce, o których piszą pedagodzy i badacze czytelnictwa, są przesadzone? Z pewnością zagadnienia obejmujące efektywność czytania e-tekstów wymagają dalszych badań, uwzględniających także eksperymenty podobne do opisanego w niniejszym artykule. Nie można bowiem wykluczyć innych czynników, oprócz natury technicznej, podkreślanych przez respondentów, mających wpływ na percepcję, a w konsekwencji recepcję tekstu. Do nich można zakwalifikować, na przykład indywidualne przyzwyczajenia respondentów związane z czynnością czytania (ulubiona pora, miejsce itp.) czy warunki zewnętrzne (otoczenie, hałas itp.).

Elementem decydującym o ostatecznych wynikach studentów mógł być także sam kwestionariusz ankiety. Zauważono, że studenci chętniej, uzyskując także większą liczbę punktów, odpowiadali na pytania zamknięte (nr 1-2, 4 i 7-8). Najgorzej pod względem liczby punktów wypadały pytania otwarte, chociaż wszystkie odnosiły się do tekstu i, oprócz pytania nr 12, dotyczyły konkretnych informacji wymienionych w prezentowanym fragmencie. Ustalenie, czy łatwość odpowiadania na dany typ pytań to przypadek czy prawidłowość,

${ }^{2}$ Do podobnych wniosków doszedł M. Maryl, porównujący w swoim eksperymencie dwie grupy czytających: jedna zapoznawała się z drukowaną wypowiedzią, druga czytała fragment tekstu literackiego wyświetlanego na ekranie laptopa. 
mająca swoje źródło na przykład w preferencjach czytelniczych lub metodach nauczania oraz weryfikowania wiedzy na niższych szczeblach edukacji, wymaga dalszych badań przy użyciu na przykład rozbudowanych kwestionariuszy ankiet i/lub wywiadów.

Wybór tekstu polecanego do przeczytania studentom w trakcie eksperymentu i jego długość również mogły wpłynąć na wyniki. Celowo zrezygnowano z literackiej wypowiedzi, aby lektura nie kojarzyła się tylko z rozrywką czy przeżyciami o charakterze estetycznym. Nie uwzględniono także tekstu stricte naukowego, który, ze względu na tematykę i terminologię, mógłby być niezrozumiały zwłaszcza dla studentów pierwszego roku. Wybór padł na wypowiedź kwalifikowaną do gatunku cieszącego się współcześnie w Polsce sporą poczytnością (biografie). Zaproponowany fragment nie zawierał specjalistycznego, trudnego słownictwa. Jego lekturę ułatwiał podział na akapity zamykające logiczne całości. Pytania tworzące kwestionariusz ułożono w takiej kolejności, aby nawiązywały do następujących po sobie partii tekstów. Mimo tych, wydawało się, ułatwień, niektórzy badani uznali tekst za zbyt trudny w lekturze.

\section{Zakończenie}

Postępująca cyfryzacja i łatwość dostępu do korzystania z tekstów za pośrednictwem urządzeń codziennego użytku, na przykład telefonów, implikuje badania z zakresu percepcji i recepcji e-tekstów, których wyniki mogą być wykorzystane nie tylko w przemyśle elektronicznym, ale także w edukacji. Przedsięwzięcia, jak na przykład Europeana, mające na celu udostępnienie dziedzictwa kulturowego całej Europy w Iinternecie, sprzyjają poszerzaniu kręgów e-czytelników i intensyfikację działań, w centrum których znajduje się komunikat w cyfrowej formie. Wprowadzanie na wszystkich szczeblach edukacji e-podręczników od najmłodszych lat kształci nawyk sięgania do elektronicznej wersji tekstu. Nauczyciele, także akademiccy, zainteresowani osiąganiem przez uczniów/studentów jak najlepszych wyników powinni zatem, podczas przygotowania materiałów dydaktycznych, uwzględniać czynniki mogące mieć wpływ na ich percepcję i recepcję. Należałoby brać pod uwagę formę (format) wypowiedzi, długość tekstu czy wreszcie urządzenie, za pośrednictwem którego uczniowie/studenci będą się z daną wypowiedzią zapoznawać.

\section{Bibliografia}

Brzezińska, A., Burtowy, M. (1985). Psychopedagogiczne problemy edukacji przedszkolnej. Poznań: Wydaw. Naukowe UAM.

Dillon, A. (1992). Reading from Paper Versus Reading from Screen: A Critical Review of the Empirical Literature. Ergonomics 35(10), 1297-1326.

Dillon, A., McKnight, C., Richardson, J. (1993). Hypertext in Context. Cambridge.

GUS (2017a). Jak korzystamy z internetu - 2016? [online]. Główny Urząd Statystyczny, [24.04.2018], http://stat.gov.pl/obszary-tematyczne/nauka-i-technika-spoleczenstwo-informacyjne/spoleczenstwo-informacyjne/jak-korzystamy-z-internetu-2016,5,1.html

GUS (2017b). Społeczeństwo informacyjne w Polsce. Wyniki badań statystycznych z lat 2013-2017 [online]. Główny Urząd Statystyczny, [24.04.2018], http://stat.gov.pl/obszary-tematyczne/ nauka-i-technika-spoleczenstwo-informacyjne/spoleczenstwo-informacyjne/spoleczenstwoinformacyjne-w-polsce-wyniki-badan-statystycznych-z-lat-2013-2017,1,11.html 
Hayles, K., N. (2010). How We Read: Close, Hyper, Machine. ADE Bulletin [online], 150, 62-79, [24.04.2018], http://nkhayles.com/how_we_read.html

Hillesund, T. (2010). Digital Reading Spaces: How Expert Readers Handle Books, the Web and Electronic Paper. First Monday [online], 15(4), [24.04.2018], http://firstmonday.org/ojs/index. $\mathrm{php} / \mathrm{fm} /$ article/view/2762/2504

Joon, K., Joan, K. (2013). Reading from a LCD Monitor Versus Paper: Teenagers' Reading Performance. International Journal of Research Studies in Educational Technology, 2(1), 15-24.

Kisilowska, M., Paul, M., Zając, M. (2016). Jak czytaja Polacy? Raport badawczy projektu Zmiany kultury czytelniczej w Polsce w kontekście upowszechnienia e-tekstów i urzadzeń pozwalajacych $z$ nich korzystać [online]. [24.04.2018],https://centrumcyfrowe.pl/wp-content/uploads/2016/06/ Jak-czytaj\%C4\%85-Polacy-raport-ko\%C5\%84cowy.pdf

Köpper, M., Mayr, S., Buchner, A. (2016). Reading from Computer Screen Versus Reading from Paper: Does It Still Make a Difference? Ergonomics, 59 (5), 615-632.

Laskowska, J. (2017). Transformacja nośników tekstu i jej wpływ na czytelnictwo studentów kierunków humanistycznych w świetle badań ankietowych. W: M. Antczak, A. Walczak-Niewiadomska (red.), Nowoczesne technologie czy tradycyjne metody? O tendencjach w krzewieniu kultury czytelniczej młodego pokolenia (73-88). Łódź, Warszawa: Wydaw. Uniwersytetu Łódzkiego, Wydaw. SBP.

Liu, Z. Huang, X. (2016). Reading on the Move: A Study of Reading Behavior of Undergraduate Smartphone Users in China. Library \& Information Science Research, 36, 235-242.

Malmquist, E. (1982). Nauka czytania w szkole podstawowej. Warszawa: Wydawnictwa Szkolne i Pedagogiczne.

Maryl, M. (2015). Życie literackie w sieci. Pisarze, instytucje i odbiorcy wobec przemian technologicznych. Warszawa: Instytut Badań Literackich PAN.

Maryl, M. (2011). Differences in Literary Reading from Print Versus Computer Screen. An Empirical Study [online]. In: F. Hakemulder (ed.), De stralende lezer. Wetenschappelijk onderzoek naar de invloed van het lezen (421-433). [24.04.2018],http://maryl.org/wp-content/uploads/2013/12/ Maryl-2011-Differences-in-literary-reading-from-print-versus-computer-screen.pdf

Park, E., Sung, J., Cho, K. (2015). Reading Experiences Influencing the Acceptance of E-book Devices. The Electronic Library, 33 (1), 120-135.

Pracownia Edukacyjnych Zastosowań Technologii Informacyjno-Komunikacyjnych NASK (2017). Raport z badania "Nastolatki 3.0” [online]. Narodowe Centrum Kultury, [2018.04.24], http://nck. $\mathrm{pl} /$ badania/raporty/raport--nastolatki-wobec-internetu-3-0-

Uliasz, A. (2010). Bibliotekarze na blogu. Poradnik Bibliotekarza, 1, 38-39.

Urząd Komunikacji Elektronicznej (2016). Badanie opinii publicznej w zakresie funkcjonowania rynku ustug telekomunikacyjnych oraz preferencji konsumentów. Raport z badania klientów indywidualnych [online]. [24.04.2018],https://archiwum.uke.gov.pl/wyniki-badania-konsumenckiegouzytkownikow-uslug-telekomunikacyjnych-21271

Walsh, A. (2012), Mobile Information Literacy: A Preliminary Outline of Information Behaviour in a Mobile Environment. Journal of Information Literacy, 6(2), 56-69. 


\section{Załącznik}

\section{Część merytoryczna ankiety}

1 Proszę wskazać tytuły utworów Zofii Nałkowskiej, o których traktuje czytany przez Panią/Pana tekst

$\square$ Niecierpliwi

Pion

Granica

Tragiczne pokolenie

Medaliony

Romans Teresy Hennert

2 Proszę zaznaczyć tytuły czasopism, w których Zofia Nałkowska drukowała fragmenty swoich powieści
Tor
Bluszcz
Wiadomości Literackie
Kurier Literacki
Gazeta Polska
Lewy Pion

3 Którą z powieści Zofii Nałkowskiej autorka czytanego przez panią Panią/Pana tekstu uznała za podsumowanie twórczości pisarki?

4 W jaki sposób autorka tekstu stara się ustalić datę ukazania się w całości pier wodruku Granicy Zofii Nałkowskiej?

$\square$ sprawdzała w oficjalnych wykazach druków

konsultowała się ze znawcami polskiej literatury okresu międzywojennego

czytała dzienniki Czesława Miłosza

sprawdzała recenzje w czasopismach okresu międzywojennego

ustalała kolejność druku odcinków powieści w czasopismach

czytała biografie Brunona Schulza i Adama Sapiehy

5 Co było znakiem uznania Granicy Zofii Nałkowskiej za jedną z najważniejszych powieści w polskiej literaturze międzywojennej?

6 Co, zdaniem autorki tekstu, bulwersowało „młodych” pisarzy w Niecierpliwych Zofii Nałkowskiej?

7 Proszę wskazać nazwiska pisarzy, których książki autorka tekstu przywołała w kontekście twórczości Zofii Nałkowskiej

Edmund Zalewski

Marian Ruth-Buczkowski

Stefan Otwinowski

Wincenty Rzymowski

Adolf Rudnicki

Wojciech Alojzy Świętosławski

8 Zaznacz określenia charakteryzujące powieść Niecierpliwi?

fantastyczna

katastroficzna 
$\square$ autobiograficzna

defetystyczna

pesymistyczna

sensacyjna

9 Proszę wymienić historyczne i jednocześnie ważne wydarzenie w biografii Zofii Nałkowskiej, mające wpływ na powstanie Medalionów.

10 Jak autorka tekstu klasyfikuje gatunkowo Medaliony Zofii Nałkowskiej?

11 Czemu, zdaniem autorki tekstu, służy prowadzenie narracji w Medalionach w liczbie pojedynczej i mnogiej?

12 Podaj przynajmniej 2 przykłady zastosowanych przez autorkę tekstu zabiegów kompozycyjnych lub/i językowych służących wartościowaniu powieści Zofii Nałkowskiej.

13 Proszę wskazać utrudnienia techniczne podczas czytania tekstu w wersji elektronicznej.

\title{
The Perception of Print and Electronic Text
}

\begin{abstract}
Purpose/Thesis: The wide spread of information and communication technologies, which is reflected in the growing availability of texts in digital forms and devices enabling their reception (laptops, tablets, smartphones), encourages us to do research on reading behaviour in the context of the growing popularity of e-texts and the devices that display them. The aim of the article is to present the results of perception and reception tests of the text in printed and electronic forms. The authors attempt to answer the research question as to whether the text medium affects the perception of the text.

Approach/Methods: An experiment was conducted among students whose task was to read the text and answer the questions related to its content. The students were divided into four groups of people reading the text from: from an A4 sheet, a 14-inch laptop, a 6-inch e-book reader and a 5-inch mobile phone.

Practical implications: The results of the research can be used in the teaching methods of academic teachers.

Originality/Value: The innovativeness of the approach in the research presented in the article is the application of an experiment to collect data which was then subjected to comparative analysis and interpretation. In Polish-language literature on text reception such an approach rarely occurs.
\end{abstract}

Keywords

Electronic device. Information storage media. Print. Text perception

Dr hab. KATARZYNA TAŁUĆ jest adiunktem w Zaktadzie Kultury Czytelniczej i Informacyjnej Instytutu Bibliotekoznawstwa i Informacji Naukowej Uniwersytetu Ślaskiego w Katowicach. Jej zainteresowania badawcze koncentruja się na problematyce kultury ksiażki i prasy, z uwzględnieniem analizy procesów komunikacyjnych zachodzacych w relacjach twórca wypowiedzi - odbiorca w ujecciu diachronicznym i synchronicznym. Wybór publikacji: M. Gwadera, K. Tatuć, Edukacja medialna i informacyjna. W: A. Tokarska (red.), Bibliotekarstwo. Warszawa 2013, 565-583.; Ksiadz Jan Kudera - badacz dziejów prasy na Ślasku. Bibliotheca Nostra. Ślaski Kwartalnik Naukowy 2015, 1(39), 94-104; Blog - narracja w stowie i obrazie. W: B. Olszewska, O. Pajaczkowski (red.), „Stare” $i$ „nowe” w literaturze dla dzieci i mtodzieży - mate formy narracyjne. Opole 2017, 119-140. 


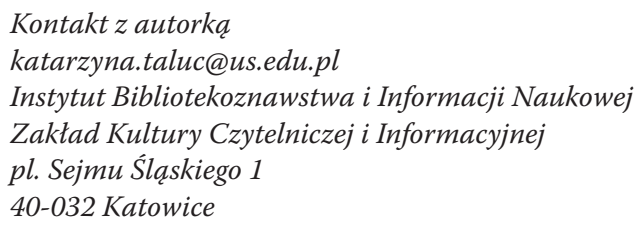

Dr hab. JACEK TOMASZCZYK jest dyrektorem Instytutu Bibliotekoznawstwa i Informacji Naukowej Uniwersytetu Ślaskiego w Katowicach $i$ adiunktem w Zakładzie Zarzadzania Informacja tego Instytutu. Specjalizuje się w informacji terminologicznej oraz indywidualnym zarzadzaniu informacja. Ważniejsze publikacje: Model systemu informacji terminologicznej, Katowice 2014. Terminologia w komunikacji naukowej. W: A. Pulikowski (red.), Kultura ksiażki i informacji. Księga jubileuszowa dedykowana Profesor Elżbiecie Gondek, Katowice 2017. Metodyka tworzenia i ewaluacji cyfrowych narzędzi indywidualnego zarzadzania informacja. W: R. Sapa (red.), Diagnostyka w zarzadzaniu informacja: perspektywa informatologiczna, Kraków 2017.

Kontakt $z$ autorem

jacek.tomaszczyk@us.edu.pl

Instytut Bibliotekoznawstwa i Informacji Naukowej

Zaktad Zarzadzania Informacja

pl. Sejmu Ślaskiego 1

40-032 Katowice 